University of Nebraska - Lincoln

DigitalCommons@University of Nebraska - Lincoln

\title{
Pollination biology of a disjunct population of the endangered sandhills endemic Penstemon haydenii S. Wats. (Scrophulariaceae) in Wyoming, USA
}

\author{
V. J. Tepedino \\ USDA ARS \\ T. L. Griswold \\ USDA ARS, terry.griswold@ars.usda.gov \\ T.R. Toler \\ Utah State University \\ B. A. Bradley \\ Juniata College \\ J. L. Hawk \\ New Orleans, LA
}

Follow this and additional works at: https://digitalcommons.unl.edu/usdaarsfacpub

Part of the Agricultural Science Commons

Tepedino, V. J.; Griswold, T. L.; Toler, T.R.; Bradley, B. A.; and Hawk, J. L., "Pollination biology of a disjunct population of the endangered sandhills endemic Penstemon haydenii S. Wats. (Scrophulariaceae) in Wyoming, USA" (2007). Publications from USDA-ARS / UNL Faculty. 232.

https://digitalcommons.unl.edu/usdaarsfacpub/232

This Article is brought to you for free and open access by the U.S. Department of Agriculture: Agricultural Research Service, Lincoln, Nebraska at DigitalCommons@University of Nebraska - Lincoln. It has been accepted for inclusion in Publications from USDA-ARS / UNL Faculty by an authorized administrator of DigitalCommons@University of Nebraska - Lincoln. 


\title{
Pollination biology of a disjunct population of the endangered sandhills endemic Penstemon haydenii S. Wats. (Scrophulariaceae) in Wyoming, USA
}

\author{
Vincent J. Tepedino $\cdot$ Trent R. Toler • \\ Brosi A. Bradley · Jessica L. Hawk • \\ Terry L. Griswold
}

Received: 25 January 2006/ Accepted: 21 November 2006/Published online: 29 December 2006

(C) Springer Science+Business Media B.V. 2006

\begin{abstract}
We studied the breeding system and flower visitors of the endangered plant, Penstemon haydenii, at several south-central Wyoming, USA occurrences. In agreement with earlier studies of the species $300 \mathrm{~km}$ to the east in Nebraska, we found Wyoming plants to be selfincompatible and pollinator-dependent for sexual reproduction. Flower visitors were several species of native bees in the families Apidae (particularly bumblebees), Halictidae (small sweat bees), and Megachilidae (especially in the genus Osmia); and the masarid wasp Pseudomasaris vespoides. Especially important was Osmia brevis, an abun-
\end{abstract}

V. J. Tepedino ( $₫)$ · T. L. Griswold

USDA ARS Bee Biology \& Systematics Lab,

Department of Biology, Utah State University,

Logan, UT 84322-5310, USA

e-mail: andrena@biology.usu.edu

T. R. Toler

Department of Biology, Utah State University,

Logan, UT 84322-5305, USA

Present Address:

T. R. Toler

HDR Engineering Inc., 3995 S 700 E, Suite 100, Salt

Lake City, UT 84107-2594, USA

B. A. Bradley

Juniata College, 1700 Moore Street, Box 1071,

Huntingdon, PA 16652, USA

J. L. Hawk

1016 Clouet St., New Orleans, LA 70117, USA dant megachilid bee, and one of only two species (the sweat bee Lasioglossum (Dialictus) pruinosum was the other) present at all five sites. As in Nebraska, fruit set did not differ between our experimental cross-pollination treatment and an open-pollinated control. However, unlike Nebras$\mathrm{ka}$, open-pollinated treatments in Wyoming produced significantly fewer seeds per fruit than the experimental out-crossing treatment. We discuss several possible explanations for seed limitation: (1) a scarcity of pollinators early in the flowering season; (2) resource competition for developing ovules on open-pollinated inflorescences but not on experimental inflorescences; (3) the deposition of self pollen through intra-inflorescence and intra-genet pollinator movements; (4) few Salleles and mating types in the Wyoming metapopulation compared to the Nebraska metapopulation, from which it likely derives.

Keywords Breeding system - Reproductive limitation - Bees · Pollinators · Beardtongue . Rare $\cdot$ Conservation

\section{Introduction}

Breeding systems of plant species may vary among populations for numerous reasons, including competition for pollinators (Barrett and Eckert 1990). Minority disadvantage in competi- 
tion for pollinators in either small populations of rare endemics (Jain 1976; Tepedino 1979; Karron 1991; Weller 1994; Aizen et al. 2002), or in populations that result from colonization (Baker 1955; Stebbins 1970) is thought to commonly drive such breeding adaptations as self-compatibility and autogamy (Levin 1972a, b; Busch 2005; Herlihy and Eckert 2005; Moeller and Geber 2005). Colonization of new, distant areas has also been hypothesized to lead to changes in pollinator service (Stebbins 1970).

In this report we apply these hypotheses about breeding systems and pollinators to a rare psammophyte of the Great Plains of North America. Penstemon haydenii S. Wats. (Scrophulariaceae) was described in 1891 and listed as endangered under the US Endangered Species Act in 1987, when the entire population was estimated at 3,000-5,000 plants at 13 sites in the sandhills of western Nebraska (Caha et al. 1998; Heidel 2005). In 1996 its range was extended westward $300 \mathrm{~km}$ when a disjunct or relictual metapopulation (Husband and Barrett 1996) was discovered in south-central Wyoming sand dunes (Fertig 2001; Heidel 2005). As P. haydenii is thought to have arisen as a hybrid of the Great Plains taxa $P$. angustifolius and $P$. grandiflorus (Freeman 1981, 1986) after the formation of sand dunes in southern and central Wyoming and western Nebraska during the late Pleistocene, 10,000-15,000 years BP (Ahlbrandt et al. 1983; Muhs et al. 1997; Mayer and Mahan 2004), the Wyoming metapopulation was likely founded by one or more colonizing episodes from Nebraska.

Results of an earlier study of part of the presumed parental population in Nebraska (Tepedino et al. in press) set a guidepost against which to compare plants in the Wyoming metapopulation. Nebraska $P$. haydenii flowers are selfincompatible (see Flessner and Stubbendieck 1992 for a contrary view), and were visited commonly by several species of nectar and pollen-collecting native bees: large apids in the genera Bombus and Habropoda, large- and intermediate-sized megachilids, primarily in the genus Osmia, and halictids in a range of sizes (Lawson et al. 1989; Tepedino et al. in press; nomenclature follows Michener 2000). There was no indication of reproductive limitation (Tepedino et al. in press). Here we ask the following questions: (1) Do P. haydenii plants in Wyoming show any evidence of self-compatibility or autogamy? (2) Is there any indication of limitation of sexual reproduction? (3) Are the important flower visitors the same, either taxonomically or ecologically, as those visiting Nebraska flowers? (4) What recommendations can we make to conservationists and land managers to enable seed production of this rare taxon?

\section{Methods}

Species description

Penstemon haydenii is a member of the subgenus Penstemon Section Coerulei (Nold 1999) which reproduces both sexually, and vegetatively by rhizomes (Fritz et al. 1992). It is characterized by thick, succulent and glaucous leaves, and boatshaped anthers that dehisce across the connective. Fragrant milky-blue to pale lavender and pink bilabiate flowers, $22-30 \mathrm{~mm}$ long and usually with nectar guides, are broadly dilated above the sepals and project horizontally from the vertical inflorescence. As is typical of Penstemon flowers, there are upper and lower pairs of anthers, and a sterile staminode (Straw 1956) which varies from hairy to hairless. The upper pair of anthers dehisce up to $24 \mathrm{~h}$ after the flower opens, and is followed by dehiscence of the lower pair. Initially, the style lies above the anthers, then descends and bends as the anthers dehisce. Occasionally, the style is bent by the time the first pair of anthers dehisces (Hawk and Tepedino in press). Typically, a few 100 flowers per ramet are produced in compact, cylindrical inflorescences (average of four per ramet), each with about ten whorls (Tepedino et al. in press).

\section{Sites}

We studied P. haydenii in 2005 at five sites in two of the three known occurrences in the Ferris Dunes, Carbon Co., WY, USA (Stokes and Gaylord 1993). Average precipitation in the area is about $25 \mathrm{~cm} /$ year, most falling in April and 
May. The sites are sparsely vegetated, early successional sand dunes at 2,000-2,400 m elevation. All but the steep Bradley Peak (BP) occurrence are attenuated on a northeast-southwest axis. The BP occurrence is at the west end of the Seminoe Mountains, and is the furthest south. The remaining four sites are part of the Bear Mountain occurrence at the east end of the Ferris Mountains. Junk Hill (JH) is about $6 \mathrm{~km}$ north of $\mathrm{BP}$ and about $1.5 \mathrm{~km}$ south of Bear Mountain East (EBM) and Bear Mountain West (WBM). The latter two steep occurrences are about 0.2$0.3 \mathrm{~km}$ apart at the closest point. The Far East Bear Mountain site (FEBM) is continuous with EBM but differs in aspect, being a spit-like sandy gulley that stretches east of the main EBM occurrence. Estimated population sizes in 2004 were: BP-500; JH-1750; EBM, FEBM-1900; WBM-800 (Heidel 2005; see also for detailed site descriptions, maps, and pictures).

\section{Breeding system}

We studied the breeding system by excluding insects from experimental inflorescences using bags fashioned from white nylon tulle with $1 \mathrm{~mm}^{2}$ mesh. Inflorescences were bagged prior to blooming, unbagged briefly for treatment and rebagged immediately thereafter. We applied four treatments in two replicates, one at each of two sites in the Bear Mountain occurrence (JH, FEBM): autogamy-automatic, unassisted, self-pollination; geitonogamy-pollination using donor pollen from fresh anthers of another flower on the same plant (a test of self-compatibility); xenogamy-pollen donor a flower on a nearby plant, usually 3-10 m, but always $>1 \mathrm{~m}$, distant); openpollinated control (FEBM only, time constraints precluded a $\mathrm{JH}$ treatment)—an unmanipulated flower at the same phenological stage as other treated flowers, but on another inflorescence, usually on the same, sometimes (thrice) on a nearby ramet when necessary. At each site, each treatment (except the control) was applied to a different flower on each of 30 (FEBM) or $14(\mathrm{JH})$ inflorescences, each on a different plant. Since untreated flowers on bagged inflorescences (always 30 or more) were unmanipulated and received no experimental pollen, there was little likelihood of reallocation of limited resources within an inflorescence (Lee 1988). We used $\chi^{2}$ statistics (including partitions) to analyze fruit production, and one-way ANOVA for seeds per fruit.

Flower visitor collections and observations

At least once per week, for 3 weeks, we collected and observed insects at the flowers throughout the day at four sites beginning June 8 . We made only one trip to the fifth site, BP, on our final day, June 27. Collections had dual purposes: specimens for identification and pollen analysis. We did not attempt to be exhaustive when collecting; if we could identify an insect (e.g., the unique wasp Pseudomasaris vespoides) we did not collect it. The collector walked through the site and captured insects seen on the flowers, either with a butterfly net or directly into a killing vial. Insects were pinned, labeled and identified later. Collections and observations were sometimes alternated but we observed more often than we collected. Observations allowed us to estimate visitation rates. Usually, one person at a site observed a known number of flowers $(x=20.5, \mathrm{SD}=5.4$, $N=56$ ) for one or more 30 -min periods in morning and afternoon, with one or more 30min collecting periods interspersed between them. Visitation rates were calculated as total visits per flower per hour (irrespective of taxon) and were also partitioned by taxonomic group. When convenient, we also recorded insect behavior on the flowers, and whether they were likely pollinators.

\section{Examination of pollen grains}

We identified pollen grains in the scopa (pollen baskets) of bees actively collecting pollen and on the bodies of all bees carrying moderate amounts of pollen. We scraped pollen from the scopa with a clean forceps, placed it on a slide, applied a drop or two of alcohol, stained with basic fuchsin and applied moderate heat (Beattie 1971). The pollen slides were examined under a compound microscope at 400×; 500 grains were categorized as either $P$. haydenii (we found no other concurrently blooming beardtongues during our study) 
or other by comparison with a reference collection. We sampled pollen only from bees that had accumulated intermediate-sized or larger pollen loads (at least some hairs in the pollen-collecting apparatus obscured by pollen); we did not sample bees with smaller pollen loads because they represented relatively few pollen-collecting visits.

We scored the distribution of pollen grains on the bodies of flower-visiting bees under a binocular scope by envisioning a line that bisected each bee transversely. The line divided the three body sections (head, thorax, abdomen) roughly into dorsal and ventral halves. We then qualitatively scored the presence of pollen grains into none-tofew or moderate-to-many for each of the six body regions. Pollen was sampled by dabbing a square of stain-impregnated gel on those body segments with appreciable pollen, and preparing slides as described above.

\section{Results}

Breeding system

The results of the breeding system studies were the same for FEBM and JH (Table 1). The xenogamy treatment flowers produced significantly more fruits than the autogamy or geitonogamy treatment flowers (FEBM, $\chi^{2}=53.4$, $d f=2, \quad P<0.0001 ; \quad \mathrm{JH}, \quad \chi^{2}=25.3, \quad d f=2$, $P<0.0001)$; the sites did not differ in the fruiting success of xenogamy flowers $\left(\chi^{2}=0.48, d f=1\right.$, $P>0.45)$.

The autogamy and geitonogamy treatment flowers set few fruits (usually none) and did not

Table 1 Results of $P$. haydenii breeding system treatments at two Wyoming sites

\begin{tabular}{lrrrr}
\hline & A & G & X & O \\
\hline Far East Bear Mountain & & & \\
Fruit & 0 & 1 & 21 & 21 \\
No fruit & 29 & 28 & 7 & 7 \\
Seeds/fruit (SD) & - & 8 & $25.0(10.2)$ & $15.9(6.2)$ \\
Junk Hill & & & & \\
Fruit & 0 & 2 & 11 & - \\
No fruit & 14 & 12 & 2 & - \\
Seeds/fruit (SD) & - & $6.5(3.5)$ & $29.1(10.1)$ & - \\
\hline
\end{tabular}

$\mathrm{A}$ = autogamy; $\mathrm{G}=$ geitonogamy; $\mathrm{X}=$ xenogamy; $\mathrm{O}=$ open-pollinated control; $\mathrm{SD}=$ standard deviation differ from each other. Only three of 43 geitonogamy flowers (and none of 43 autogamy flowers) set fruit; the three geitonogamously produced fruits produced a total of 21 seeds. For comparison, xenogamously produced fruits contained an average of about 25 seeds at FEBM and 29 at JH; there was no significant difference between the two sites $(t=1.10, d f=30, P=0.28)$.

\section{Reproductive limitation}

There is preliminary evidence that open-pollinated seed production at both sites was less than an average flower's capacity. While there was no difference in fruit set at FEBM between the xenogamy treatment and the open-pollinated control treatment (Table 1), there was a significant difference in the number of seeds per fruit: open-pollinated flowers produced fewer seeds ( $t=2.57, d f=29, P=0.016)$. Comparison of the xenogamy treatment at $\mathrm{JH}$ with the open-pollinated sample from FEBM, gave a similar result $(t=3.56, d f=19, P=0.002)$.

\section{Flower visitors}

We collected 26 species of bees across the five sites (Table 2). The masarid wasp, Pseudomasaris vespoides, a Penstemon specialist (Cooper 1952; Torchio 1974), was present in moderate numbers at all sites but was not collected. Other flower visitors, e.g., dipterans, lepidopterans, were uncommon. In total, 19 of these species were either incidentals ( 17 were represented by one or two individuals and two by three) or species that have been recorded frequently on Penstemon flowers elsewhere but were uncommon on the Ferris Dunes (e.g., Habropoda morrisoni). The number of species collected was not related to collecting effort: most species were captured at FEBM, where most effort was expended but the least effort yielded the second largest number of species (BP). Only two species, the Penstemon specialist Osmia brevis (Crosswhite and Crosswhite 1966; Tepedino et al. 1999; unpublished data) and the generalist, Lasioglossum (Dialictus) pruinosum (unpublished data), were present at all sites. 
Table 2 Bee species collected from $P$. haydenii at five sites in Carbon Co., WY, with numbers collected /numbers with pollen loads $(\mathrm{NC} / \mathrm{P})$ and mean $( \pm \mathrm{SD})$ percentage of $P$. haydenii pollen in the pollen loads $(\% \mathrm{Ph})$

\begin{tabular}{|c|c|c|c|c|c|c|c|}
\hline Species & FEBM & EBM & WBM & $\mathrm{JH}$ & $\mathrm{BP}$ & $\mathrm{NC} / \mathrm{P}$ & $\% \mathrm{Ph}$ \\
\hline Andrena sp. & $\mathrm{X}$ & & & & & $1 / 1$ & 99.6 \\
\hline A. sp. 1 & & & & & $\mathrm{X}$ & $1 / 0$ & - \\
\hline A. sp. 2 & & & & & $\mathrm{X}$ & $1 / 1$ & 1.1 \\
\hline A. sp. 3 & & & & & $\mathrm{X}$ & $1 / 0$ & - \\
\hline Lasioglossum(Dialictus) albohirtum (Crawford) & $\mathrm{X}$ & & & & & $2 / 2$ & $89.2 \pm 6.5$ \\
\hline L. (Dialictus) pruinosum (Robertson) & $\mathrm{X}$ & $\mathrm{X}$ & $\mathrm{X}$ & $\mathrm{X}$ & $\mathrm{X}$ & $60 / 35$ & $83.4 \pm 25.6$ \\
\hline L. (Lasioglossum) sisymbrii (Cockerell) & $\mathrm{X}$ & $\mathrm{X}$ & & & $\mathrm{X}$ & $8 / 8$ & $80.8 \pm 14.3$ \\
\hline L. (Dialictus) sp. $A$ & $\mathrm{X}$ & & & & $\mathrm{X}$ & $2 / 2$ & $70.9 \pm 40.9$ \\
\hline L. (Lasioglossum) trizonatum (Cresson) & & & & & $\mathrm{X}$ & $3 / 3$ & $50.8 \pm 43.7$ \\
\hline Agapostemon splendens (Lepeletier) ${ }^{\mathrm{a}}$ & $\mathrm{X}$ & $\mathrm{X}$ & $\mathrm{X}$ & & & $8 / 4$ & $57.1 \pm 46.7$ \\
\hline A. angelicus/texanus ${ }^{\mathrm{a}}$ & $\mathrm{X}$ & & & & & $1 / 0$ & - \\
\hline Halictus tripartitus Cockerell & & & & & $X$ & $1 / 1$ & 98.4 \\
\hline Osmia brevis Cresson & $\mathrm{X}$ & $\mathrm{X}$ & $\mathrm{X}$ & $\mathrm{X}$ & $\mathrm{X}$ & $94 / 86$ & $93.4 \pm 13.9$ \\
\hline O. cyaneonitens Cockerell ${ }^{\mathrm{a}}$ & $\mathrm{X}$ & $\mathrm{X}$ & $\mathrm{X}$ & & $\mathrm{X}$ & $5 / 3$ & $97.4 \pm 0.9$ \\
\hline O. integra Cresson $^{\mathrm{a}}$ & $\mathrm{X}$ & $\mathrm{X}$ & $\mathrm{X}$ & & & $15 / 13$ & $65.9 \pm 37.5$ \\
\hline O. proxima Cresson & $\mathrm{X}$ & & & & & $2 / 2$ & $52.7 \pm 60.1$ \\
\hline O. sanrafaelae Parker & $\mathrm{X}$ & & & & & $1 / 1$ & 24.0 \\
\hline Atoposmia (Atoposmia) n.sp. 6 & $X$ & $\mathrm{X}$ & & & & $3 / 1$ & 100 \\
\hline Ceratina neomexicana Cockerell & & & & & $\mathrm{X}$ & $2 / 2$ & $75.5 \pm 17.7$ \\
\hline Eucera fulvitarsis (Cresson) & $\mathrm{X}$ & & & & & $1 / 0$ & - \\
\hline Anthophora sp. & & & $\mathrm{X}$ & & & $1 / 0$ & - \\
\hline Habropoda morrisoni (Cresson) $)^{\mathrm{a}}$ & & & & $\mathrm{X}$ & & $1 / 1$ & 7.4 \\
\hline Bombus appositus Cresson & & & $\mathrm{X}$ & & & $1 / 1$ & 98.4 \\
\hline B. centralis (Cresson) & $\mathrm{X}$ & & $\mathrm{X}$ & & & $2 / 2$ & $52.0 \pm 67.6$ \\
\hline B. fervidus (Fabricius) ${ }^{\mathrm{a}}$ & & $\mathrm{X}$ & $\mathrm{X}$ & & $\mathrm{X}$ & $4 / 4$ & $46.7 \pm 40.8$ \\
\hline B. huntii Greene ${ }^{\mathrm{a}}$ & & $\mathrm{X}$ & $\mathrm{X}$ & & & $2 / 2$ & $96.4 \pm 5.1$ \\
\hline Total species & 15 & 9 & 10 & 3 & 12 & & \\
\hline Total (min/days) & $270-3$ & $300-3$ & $330-3$ & $180-4$ & $270-1$ & & \\
\hline
\end{tabular}

Total minutes and number of days spent at each site indicates collecting effort. Site abbreviations as in text

a Denote species collected in both Wyoming and Nebraska

Osmia brevis females foraged for both nectar and pollen. Initially, they gathered pollen by rubbing head and thorax across the anthers before transferring pollen to the ventral scopa (Fig. 1). Like their Nebraska conspecifics, Lasioglossum species crawled down the corolla tube, presumably for nectar, and collected pollen by addressing the anthers directly while hanging from the stamens in an inverted position. In so doing, they also contacted the stigma and accumulated much pollen on the ventral thorax and abdomen (Fig. 1). Most $O$. brevis and Lasioglossum females collected pollen, and had high percentages of Penstemon pollen in their scopa (Table 2).

Flower-visitation rates

On average, flowers were visited at least once (usually twice) per hour at all sites though variation both between and within sites was considerable (Table 3). Visits by Osmia bees were most common at all but the JH site. Halictid bees were present at all sites but were common visitors at only two sites. Visitation by other taxa was uncommon.

We found differences in flower-visitation rates among days within sites, but not across times. At three of the four sites (FEBM, EBM, WBM), flower visitation increased with date (Fig. 2). At all three sites, the increase was due both to an increase in Osmia bees (almost all $O$. brevis), and to a simultaneous decrease in the number of available flowers as the bloom season waned. The $\mathrm{JH}$ site showed a decrease in visitation rates between the initial and subsequent observation days. The decline was due to a decrease in both Osmia and Lasioglossum bees. 
Fig. 1 The percent of total bees that carried moderate to many $P$. haydenii pollen grains on each of six body sections ( $\mathrm{D}=$ dorsal; $\mathrm{V}=$ ventral; $\mathrm{H}=$ head; $\mathrm{T}=$ thorax; $\mathrm{A}=$ abdomen). Species are grouped by family, $\mathrm{A}=$ Megachilidae; $\mathrm{B}=$ Halictidae; species abbreviations identifiable by comparison with complete names in Table 2
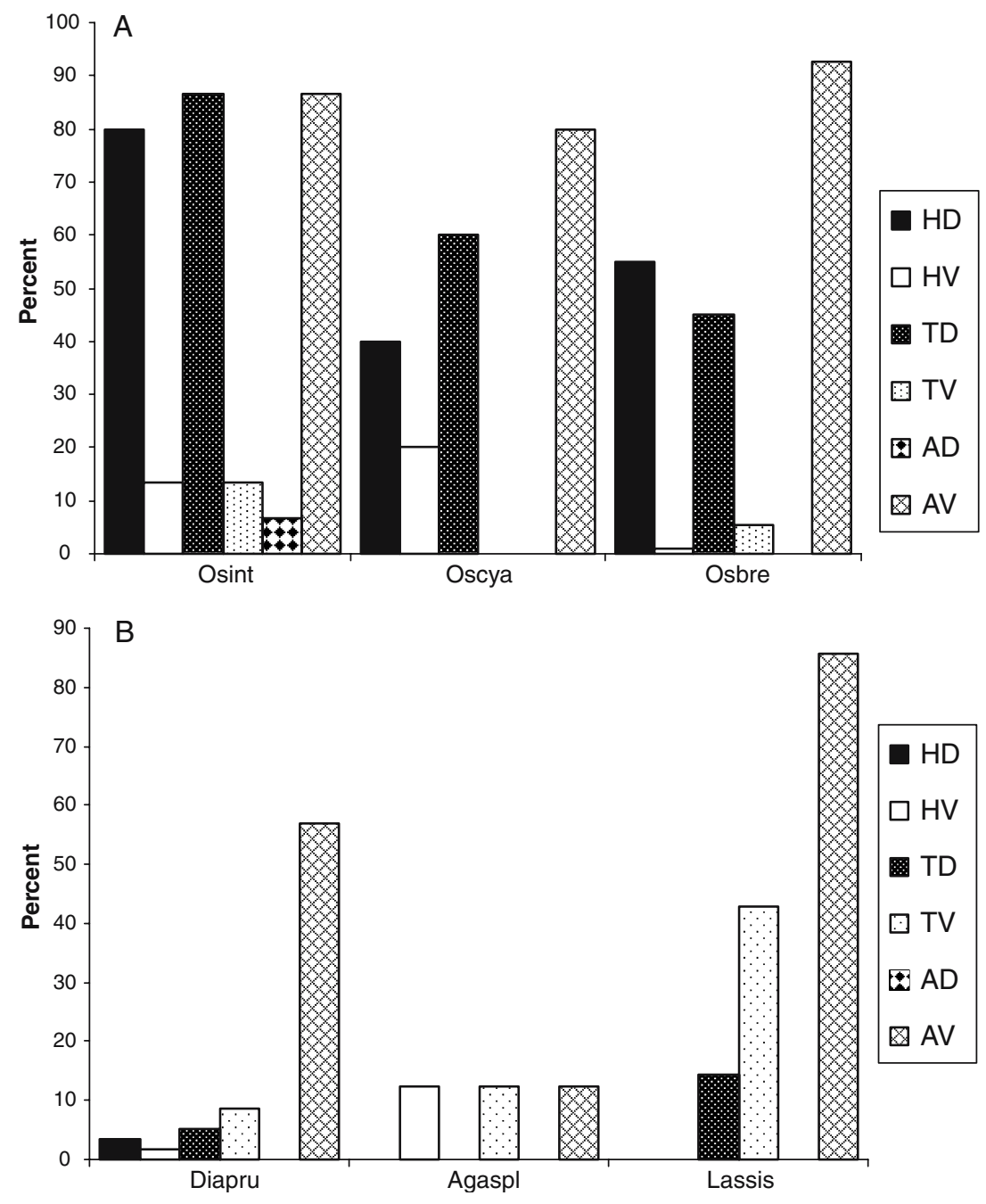

Table 3 Mean $( \pm \mathrm{SD})$ bee visits/flower/hour $(\mathrm{VFH})$ at five Wyoming sites

\begin{tabular}{lccccc}
\hline & BP & JH & WBM & EBM & FEBM \\
\hline Mean VFH & 1.19 & 1.99 & 2.39 & 1.68 & 2.06 \\
\pm SD & 1.41 & 3.32 & 2.51 & 2.24 & 2.84 \\
Range & $0-3.3$ & $0-12.5$ & $0-8.3$ & $0-8.5$ & $0-14.7$ \\
$N$ & 9 & 15 & 15 & 21 & 34 \\
Osmia & 0.56 & 0.57 & 2.09 & 1.34 & 1.49 \\
Halictids & 0.54 & 1.31 & 0.10 & 0.28 & 0.15 \\
Bombus & 0.03 & 0.0 & 0.18 & 0.04 & 0.22 \\
Pseudomasaris & 0.05 & 0.11 & 0.02 & 0.02 & 0.19 \\
Minutes & 270 & 425 & 445 & 630 & 1080 \\
\hline
\end{tabular}

Observation effort at each site indicated by minutes observed and number of observation periods $(N)$. Mean $\mathrm{VFH}$ is also partitioned by taxa at lowest level recognizable in field. Site abbreviations as in text
There were no clear visitation differences between morning and afternoon (Table 4). Halictid and Osmia bees, and Pseudomasaris wasps distributed their flower visits equally throughout the day. Only bumblebees seemed to express a preference for morning visits but they were uncommon at all sites except FEBM and statistical comparisons are inadvisable.

Examination of pollen loads

The most common bee species on $P$. haydenii flowers tended to collect the most $P$. haydenii pollen. Only six species were captured five or more times on the flowers across all sites 

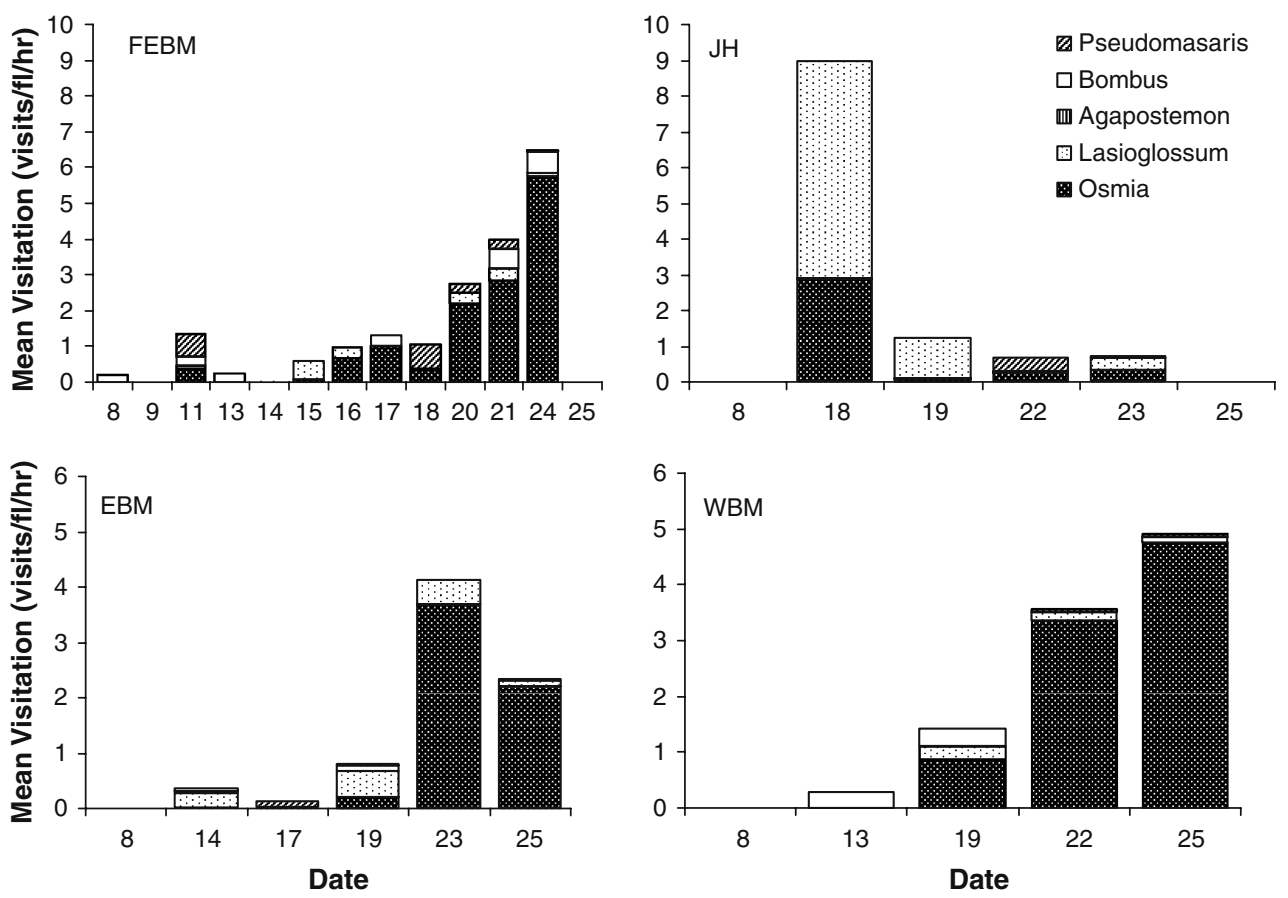

Fig. 2 Visitation rates to flowers of P. haydenii by five taxa of bees at four sites in south-central Wyoming, June 2005. Site abbreviations as in text

(Table 2). These six species carried between 5797\% Penstemon pollen in their scopae (mean $=79.7 \% \pm 15.6)$. The three most common species averaged $80.9 \%$ Penstemon pollen. Species captured fewer than five times were collecting less Penstemon pollen ( mean $=64.2 \% \pm 34.1$ ) and were more variable in the percent they carried (range 1-100\%).

Examination of body pollen

Pollen distribution across the bodies of bee species represented by five or more females that carried at least moderate amounts of Penstemon pollen grains on the six body parts is shown in Fig. 1. Individuals of the large species of Osmia tended to carry pollen on the dorsal, but not the ventral, head and thorax. They carried little pollen on the dorsal abdomen. The high numbers of Osmia bees with pollen on the ventral abdomen is due to the ventral scopa. In contrast, Lasioglossum (Dialictus) pruinosum carried little pollen anywhere except the ventral abdomen. Lasioglossum sisymbrii females carried moderate or greater amounts of pollen on the ventral thorax and abdomen. These halictids appear to carry

Table 4 The percent of collecting periods at each site in which at least one flower visit was made by the taxa shown

\begin{tabular}{|c|c|c|c|c|c|c|c|c|c|}
\hline \multirow[t]{2}{*}{ Site } & \multirow[t]{2}{*}{$N$} & \multicolumn{2}{|c|}{ Osmia } & \multicolumn{2}{|c|}{ Halictids } & \multicolumn{2}{|c|}{ Bombus } & \multicolumn{2}{|c|}{ Pseudomasaris } \\
\hline & & $\mathrm{AM}$ & $\mathrm{PM}$ & $\mathrm{AM}$ & $\mathrm{PM}$ & $\mathrm{AM}$ & PM & $\mathrm{AM}$ & PM \\
\hline BP & $3 / 6$ & 66.7 & 66.7 & 66.7 & 66.7 & 33.3 & 0.0 & 33.3 & 0.0 \\
\hline $\mathrm{JH}$ & $6 / 9$ & 16.7 & 55.6 & 33.3 & 55.6 & 0.0 & 0.0 & 16.7 & 11.1 \\
\hline WBM & $8 / 7$ & 75.0 & 42.9 & 25.0 & 42.9 & 50.0 & 0.0 & 12.5 & 14.3 \\
\hline EBM & $9 / 12$ & 44.4 & 66.7 & 44.4 & 66.7 & 22.2 & 8.3 & 11.1 & 8.3 \\
\hline FEBM & $21 / 15$ & 61.9 & 60.0 & 52.4 & 20.0 & 28.6 & 20.0 & 19.0 & 26.7 \\
\hline$\sum$ & $47 / 49$ & 55.3 & 59.2 & 44.6 & 46.9 & 27.7 & 8.2 & 17.0 & 14.3 \\
\hline
\end{tabular}

$\mathrm{AM}=$ before 12:00 h; PM = after 12:00 h. $N=$ number of AM/PM observation periods. Site abbreviations as in text 
larger amounts of pollen on their ventral surface because of the upside-down manner in which they address the anthers when foraging for pollen (Tepedino et al. in press).

\section{Discussion}

The predictions of Baker (1955), Stebbins (1970) and many others, that self-compatibility and autogamy more often assure sexual reproduction in disjunct and peripheral plant populations than in centrally located populations, are frequently confirmed (e.g., Busch 2005; Moeller and Geber 2005). Such predictions of reproductive assurance also sometimes hold for small, compared to large, populations (e.g., Stone et al. 2006) and are also thought to apply to populations of rare plants (e.g., Jain 1976). They were not, however, confirmed for this disjunct population of the rare $P$. haydenii in Wyoming, where plants were neither autogamous nor self-compatible. The mating system of Wyoming plants was indistinguishable from that of plants in the presumed parental population in Nebraska (Tepedino et al. in press). This is likely due, at least in part, to the highly attractive, nectar and pollen-rich, flowers, and to the abundance of plants in the areas of study. Indeed, $P$. haydenii seems another example of a locally "common" rare plant (Lesica et al. 2006).

Studies of the pollination biology of species with disjunct distributions are less frequent for rarities such as $P$. haydenii than for common species (e.g., Robertson and Wyatt 1990; Sánchez-LaFuente 2002). In studies of more common species, visitors to distant populations sometimes differ substantially from those in large, central populations, sometimes in agreement with differences in flower characteristics. For example, Sánchez-LaFuente (2002) found larger pollinators to be more effective visitors where flowers were larger. However, close agreement between plant and pollinator morphology is by no means universal (Herrera 1996), and patterns of plant-pollinator association are frequently circumstantial.

A comparison of pollinators of disjunct populations of Opuntia, Krameria, Prosopis, and Helianthus between the Sonoran Desert of Arizona
(USA) and the dry oak-juniper grasslands of central Texas, approximately $1,300 \mathrm{~km}$ to the east, is instructive: Simpson and Neff (1987) found no common pattern of plant-pollinator association. Opuntia flowers in Arizona and Texas were pollinated primarily by bees in the genera Diadasia and Lithurgus, in many cases the same species. Results for Krameria were similar: species of the bee genus Centris were common visitors in both areas. In contrast, there was little overlap in Prosopis pollinators between Arizona and Texas, possibly because of its generalized pollination system. Prosopis is also thought to have extended its distribution east from Arizona to Texas fairly recently. Conversely, Helianthus is thought to have originated in Texas and dispersed west to Arizona with some of its many specialist pollinators. In Arizona it also attracted bees specialized on other taxa of Asteraceae. Thus, plant taxa differ with circumstance in the similarity of their pollinators in disjunct areas.

Of these examples, $P$. haydenii most resembles Helianthus. Evidently, a few bee species either followed it to Wyoming or were already present and were soon joined by other local generalists and specialists. Although only 7 of 45 bee species collected on $P$. haydenii in Wyoming and Nebraska were present in both areas (Table 2), the faunas are similar in taxonomic relatedness of visitors and in their size and behavior on the flowers. Indeed, they might be regarded as ecological equivalents. For example, in Wyoming, the western species Osmia brevis appears to fill the role of the more easterly distributed $O$. distincta in Nebraska. Though $O$. brevis is larger, both species collect nectar, and accumulate pollen on the dorsal head and thorax before packing it into the ventral scopa. Several species of Lasioglossum (Dialictus) in Nebraska are replaced by several others of similar size and behavior in Wyoming. Bumblebees are about equally abundant in both areas with some overlap in species. The most striking difference between the metapopulations involves three bee species, two of which (O. cyaneonitens, Habropoda morrisoni) were abundant in Nebraska but uncommon in Wyoming. The third species, Hoplitis pilosifrons, a megachilid with an easterly distribution, was 
abundant in Nebraska but absent in Wyoming where no analogous species was obvious.

We uncovered preliminary evidence that flowers in Wyoming (but not Nebraska) experienced reproductive limitation (Table 1): significantly fewer seeds per fruit were produced in the open-pollinated treatment than in the xenogamy treatment. This finding is tentative for at least two reasons: (1) it is based on a moderate sample size of 28 open-pollinated flowers and could be biassed (although it agrees with another set of open-pollinated flowers whose staminodes were removed; Hawk and Tepedino in press); (2) reproductive limitation is most accurately applied to the whole plant (Zimmerman and Pyke 1988); the under-producing, open-pollinated control flowers all opened and senesced before the sudden increase in pollinator visitation rates (Fig. 2) and may demonstrate seasonal pollinator limitation (Price et al. 2005) which could be compensated for by increased seed production from flowers produced later in the season.

Assuming that reproductive limitation in openpollinated flowers is real, there are at least four potential explanations: (1) pollinator limitation; frequently advanced as an explanation for reduced reproduction (e.g., Burd 1994), low early visitation rates (Fig. 2) make it a possibility here; (2) competition for limited resources among developing ovules of unbagged, open-pollinated control inflorescences, most of whose flowers developed fruits. In contrast, on bagged experimental inflorescences, competition for resources was minimal as only xenogamously treated flowers developed; all other flowers were either pollinated with self pollen or were untreated and ovules did not develop.

The remaining two possibilities are genetic: (3) excessive deposition of incompatible self-pollen on stigmas because of pollinator movements either between flowers (a) within inflorescences, or (b) between inflorescences of different ramets of the same genet. $P$. haydenii reproduces vegetatively from rhizomes (Fritz et al. 1992); thus, many inter-inflorescence moves may be self-pollinations. Aigner (2004) has recently provided an example of seed set positively related to clonal diversity in self-incompatible Dithyrea maritima. A test of this explanation requires comparison of clonal diversity in Wyoming populations with those in Nebraska, where reproductive limitation was not detected (Tepedino et al. in press). Fourth, there may be a paucity of mating types (S-alleles) in the derivative Wyoming population due to the founder effect and/or genetic drift, as DeMauro (1993) found for the lakeside daisy, Hymenoxys acaulis var. glabra. A paucity of mating types would increase the number of incompatible pollen depositions.

Characterizing the occurrence and frequency of reproductive limitation is important and awaits future pollination and genetic studies. Genetic studies currently underway (Univ. of Wyoming) may reveal whether clonal diversity in Wyoming populations is lower than that in Nebraska populations. If so, then enrichment of the Wyoming metapopulation with genetic material from $\mathrm{Ne}$ braska through techniques developed and employed by Flessner and Stubbendieck (1989) should be considered.

Acknowledgements Funding was supplied by USDIBureau of Land Management in Rawlins WY. We especially thank Frank Blomquist of that office for discovering the plant in Wyoming in 1996, for initiating the study that made this project possible, and for providing support throughout. Bonnie Heidel, Wyoming Natural Diversity Database, Univ. of Wyoming, Laramie, was also instrumental in facilitating this research. Alice Bain helped with the fieldwork.

\section{References}

Ahlbrandt TS, Swinehart JB, Maroney DG (1983) The dynamic Holocene dune fields of the Great Plains and Rocky Mountain Basins, USA. In: Brookfield ME, Ahlbrandt TS (eds) Developments on sedimentology, vol 38, Eolian sediments and processes. Elsevier, New York, pp 379-406

Aigner PA (2004) Ecological and genetic effects on demographic processes: pollination, clonality and seed production in Dithyrea maritima. Biol Conserv 116:27-34

Aizen MA, Ashworth L, Galetto L (2002) Reproductive success in fragmented habitats: do compatibility systems and pollination specialization matter? J Veg Sci 13:885-892

Baker HG (1955) Self-compatibility and establishment after "long-distance" dispersal. Evolution 9:347-348

Barrett SCH, Eckert CG (1990) Variation and evolution of mating systems in seed plants. In: Kawano S (ed), Biological approaches and evolutionary trends in plants. Academic Press, New York, pp 229-254 
Beattie AJ (1971) A technique for the study of insectborne pollen. Pan-Pac Entomol 47:82

Burd M (1994) Bateman's principle and plant reproduction: the role of pollen limitation in fruit and seed set. Bot Rev 60:83-139

Busch JW (2005) The evolution of self-compatibility in geographically peripheral populations of Leavenworthia alabamica (Brassicaceae). Am J Bot 92:15031512

Caha CA, Lee DJ, Stubbendieck J (1998) Organellar genetic diversity in Penstemon haydenii (Scrophulariaceae): an endangered plant species. Am J Bot 85:1704-1709

Cooper KW (1952) Records and flower preferences of masarid wasps. II. Polytrophy or oligotrophy in Pseudomasaris? Am Midl Nat 48:103-110

Crosswhite FS, Crosswhite CD (1966) Insect pollinators of Penstemon Series Graciles (Scrophulariaceae) with notes on Osmia and other Megachilidae. Am Midl Nat 76:450-467

DeMauro MM (1993) Relationship of breeding system to rarity in the lakeside daisy (Hymenoxys acaulis var. glabra). Conserv Biol 7:542-550

Fertig W (2001) 2000 survey for Blowout Penstemon (Penstemon haydenii) in Wyoming. US Department of the Interior, Bureau of Land Management, Cheyenne WY 40 pp. http://uwadmnweb.uwyo.edu/WYNDD/Reports/pdf_fertig/Fertig_01_Penstemon_haydenii.pdf

Flessner TR, Stubbendieck J (1989) Propagation of Blowout Penstemon (Penstemon haydenii S. Watson). In: Bragg TB, Stubbendieck J (eds) Proceedings of the 11th North American Prairie conference, Lincoln, NE, pp 237-239

Flessner TR, Stubbendieck J (1992) Pollination characteristics of Blowout Penstemon (Penstemon haydenii S. Watson). Trans Nebr Acad Sci 19:63-66

Freeman CC (1981) A biosystematic study of the genus Penstemon (Scrophulariaceae) in the Great Plains. MS Thesis, Kansas State University, Manhattan, KS

Freeman CC (1986) Penstemon. In: Flora of the great plains. Great Plains Assoc., University Press of Kansas, Lawrence, KS, pp 774-789

Fritz M, Stubbendieck J, Jobman W (1992) Blowout penstemon (Penstemon haydenii S. Wats.) recovery plan. US Fish and Wildlife Service, Denver, CO. http://ecos.fws.gov/docs/recovery_plans/1992/ 920717.pdf

Hawk JL, Tepedino VJ (in press) The effect of staminode removal on female reproductive success in a Wyoming population of the endangered Blowout penstemon, Penstemon haydenii S. Wats. (Scrophulariaceae). Madroño 54

Heidel B (2005) Survey of Penstemon haydenii (Blowout Penstemon) in Wyoming 2004. US Department of the Interior, Bureau of Land Management, RawlinsCasper, WY. http://uwadmnweb.uwyo.edu/wyndd/Reports/reports_heidel.htm

Herlihy CR, Eckert CG (2005) Evolution of self-fertilization at geographical range margins? A comparison of demographic, floral, and mating system variables in central vs. peripheral populations of Aquilegia canadensis (Ranunculaceae). Am J Bot 92:744-751

Herrera CM (1996) Floral traits and plant adaptation to insect pollinators: a devil's advocate approach. In: Lloyd DG, Barrett SCH (eds), Floral biology. Chapman \& Hall, New York, pp 65-87

Husband B, Barrett SCH (1996) A metapopulation perspective in plant population biology. J Ecol 84:461-469

Jain SK (1976) The evolution of inbreeding in plants. Annu Rev Ecol Syst 7:469-495

Karron JD (1991) Patterns of genetic variation and breeding systems in rare plant species. In: Falk DA, Holsinger KE (eds) Genetics and conservation of rare plants. Oxford University Press, New York, pp 87-98

Lawson HR, Tepedino VJ, Griswold TL (1989) Pollen collectors and other insect visitors to Penstemon haydenii S. Wats. In: Bragg TB, Stubbendieck J (eds) Proceedings of the 11th North American Prairie conference, Lincoln, NE, pp 233-235

Lee TD (1988) Patterns of fruit and seed production. In: Lovett Doust J, Lovett Doust L (eds) Plant reproductive ecology: patterns and strategies. Oxford University Press, New York, pp 179-202

Lesica P, Yurkewycz R, Crone EE (2006) Rare plants are common where you find them. Am J Bot 93:454-459

Levin DA (1972a) Low frequency disadvantage in the exploitation of pollinators by corolla variants in Phlox. Am Nat 106:453-460

Levin DA (1972b) Competition for pollinator service: a stimulus for the evolution of autogamy. Evolution 26:668-674

Mayer JH, Mahan SA (2004) Late quaternary stratigraphy and geochronology of the western Killpecker Dunes, Wyoming, USA. Quaternary Res 61:72-84

Michener CD (2000) The bees of the world. Johns Hopkins Univ Press, Baltimore, MD

Moeller DA, Geber MA (2005) Ecological context of the evolution of self-pollination in Clarkia xantiana: population size, plant communities, and reproductive assurance. Evolution 59:786-799

Muhs DR, Stafford Jr TW, Swinehart JB, Cowherd SD, Mahan SA, Bush CA, Madole RF, Maat PB (1997) Late Holocene eolian activity in the mineralogically mature Nebraska sand hills. Quaternary Res 48:162-176

Nold R (1999) Penstemons. Timber Press, Portland, OR

Price MV, Waser NM, Irwin RE, Campbell DR, Brody AK (2005) Temporal and spatial variation in pollination of a montane herb: a seven-year study. Ecology 86:2106-2116

Robertson JL, Wyatt R (1990) Evidence for pollination ecotypes in the yellow-fringed orchid, Platanthera ciliaris. Evolution 44:121-133

Sánchez-LaFuente AM (2002) Floral variation in the generalist perennial herb Paeonia broteroi (Paeoniaceae): differences between regions with different pollinators and herbivores. Am J Bot 89:1260-1269

Simpson BB, Neff JL (1987) Pollination ecology in the arid southwest. Aliso 11:417-440

Stebbins GL (1970) Adaptive radiation of reproductive characteristics in Angiosperms, I: Pollination mechanisms. Annu Rev Ecol Syst 1:307-326 
Stokes S, Gaylord DR (1993) Optical dating of Holocene dune sands in the Ferris dune field. Quaternary Res 39:274-281

Stone JL, Sasuclark MA, Blomberg CP (2006) Variation in the self-compatibility response within and among populations of the tropical shrub Witheringia solanacea (Solanaceae). Am J Bot 93:592-598

Straw RM (1956) Adaptive morphology of the Penstemon flower. Phytomorphology 6:112-119

Tepedino VJ (1979) The importance of bees and other insect pollinators in maintaining floral species composition. In: The endangered species: a symposium. Great Basin Nat Memoirs 3:139-150

Tepedino VJ, Sipes SD, Griswold TL (1999) The reproductive biology and effective pollinators of the endangered beardtongue Penstemon penlandii (Scrophulariaceae). Plant Syst Evol 219:39-54
Tepedino VJ, Bowlin WR, Griswold TL (in press) The pollination biology of the endangered Blowout Penstemon (Penstemon haydenii S. Wats.: Scrophulariaceae) in Nebraska. J Torrey Bot Soc 134

Torchio PF (1974) Mechanisms involved in the pollination of Penstemon visited by the masarid wasp, Pseudomasaris vespoides (Cresson). Pan-Pac Entomol 50:226-234

Weller SG (1994) The relationship of rarity to plant reproductive biology. In: Bowles ML, Whelan CJ (eds) Restoration of endangered species: conceptual issues, planning and implementation. Cambridge University Press, New York, pp 90-117

Zimmerman M, Pyke GH (1988) Reproduction in Polemonium: assessing factors limiting seed set. Am Nat 131:723-738 